\title{
STYLISTIC APPROACH OF JULIAN THE EMPEROR AND GREGORY NAZIANZEAN
}

\author{
George Alexandropoulos \\ University of Athens
}

\section{ABSTRACT}

This study examines the rhetorical practice in both orators, Gregory Nazianzean and Julian the Emperor. Its purpose is to describe their style and explain the way of their rhetoric choices into a multidisciplinary framework.

\section{INTRODUCTION}

For the stylistic comparison between these two orators this study is based on three invective texts ${ }^{1}$. Julian had written a political speech against Galileos and then Gregory the Theologian wrote in reply two invective speeches ${ }^{2}$. Based on these political speeches, this study aims to define their political and rhetorical strategies combining the traditional rhetoric practice with text linguistic, computational tools. Creating a corpus $^{3}$ we can have the opportunity to examine these speeches focusing on the shared, common persuasive strategies used by both orators even though they were opponents in the theological and political field. For this reason we use a variety of linguistic theories, such as Mann \& Thompson Rhetorical Structure Theory (1986 1988), Searle's speech acts categorization (1969'1979.19941996a,b), Fairclough theories (1992-2000), Fairclough and Wodak theories (1997), van Dijk framework (1999 2001) and computational tools such as AntConc ${ }^{4}$. The examined corpus consists of two of Gregory's speeches (first invective: 18, 097 words, second invective: 7, 530 words) and one political speech of Julian (10, 730 words).

\section{STYLISTIC CHOICES}

\footnotetext{
${ }^{1}$ For the text of these speeches see Bernardi et al. (1978), Migne (1857-1866), Wright (1912-1913).

${ }^{2}$ For more details about the content of these speeches see McGuckin (2001) and Athanassiadi (1992).

${ }^{3}$ For more details about the corpus linguistics see Biber \& Reppen (2011).

${ }^{4}$ Antconc is a freeware concordancer software program.
} 
Both Julian the emperor and Gregory the theologian resort to certain rhetoric ${ }^{5}$ strategies in order to persuade the public. Each one evokes all the classical rhetoric Aristotle's concepts of ethos, pathos and logos ${ }^{6}$.

\subsection{Questions with answer}

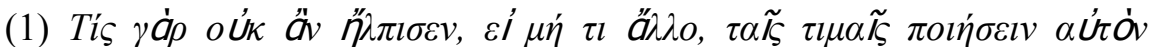

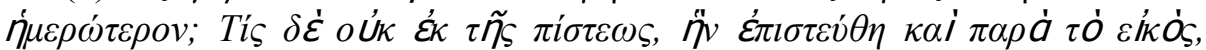

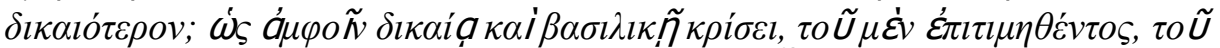

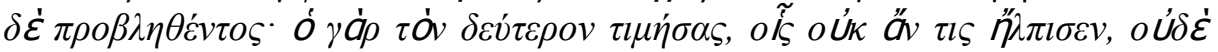

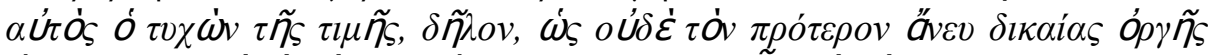

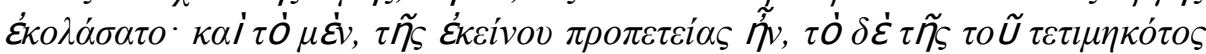
$\varphi \imath \lambda \alpha \nu \theta \rho \omega \pi i \alpha \varsigma$.

(Gregory Nazianzean's First Invective against Julian the Emperor 40)

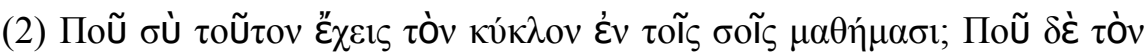

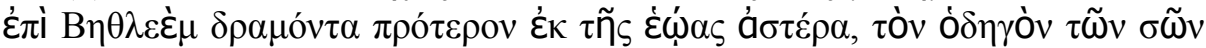

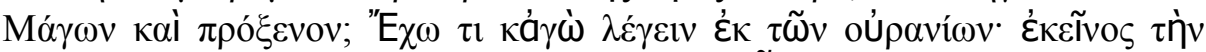

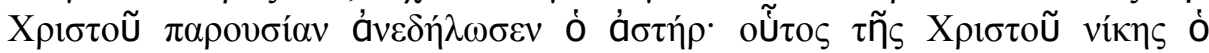

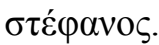

(Gregory Nazianzean's Second Invective against Julian the Emperor 5)

(3) Nvvì $\delta \varepsilon \dot{~ \varepsilon ́ \pi \alpha v \alpha \lambda \eta \pi \tau \varepsilon ́ o v ~ \varepsilon ́ \sigma \tau i ́ ~ \mu o r ~ \pi \rho o ̀ s ~ \alpha u ̉ \tau o v ́ \varsigma ~ \delta ı a ̀ ~ \tau i ́ ~ \gamma a ̀ ~ o u ̉ \chi i ̀ ~}$

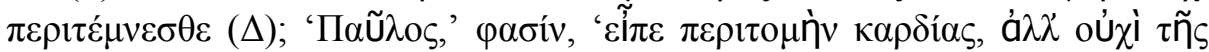

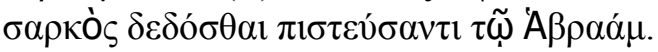

(Julian Against Galileos 351a)

In the above examples Julian and Gregory use directive speech acts through their questions and their answers with representative speech acts they give certain details to the public. The reason why orators use this stylistic choice is to motivate the public or the ideological opponent making them feel that they can participate into the structure of his speech. So, in this way question leads to involvement ${ }^{7}$ and answer to promotion of the text producer's opinion. This rhetorical strategy reminds us of the Socratic method of inducing an agreement by leading the audience to a certain thinking process through the answer as a provided solution.

\subsection{Repetition}

\footnotetext{
${ }^{5}$ For more details about rhetoric strategies see Borg (2007) and Johnstone (1989).

${ }^{6}$ See Roberts (1984).

${ }^{7}$ See Chafe (1982).
} 
VOLUME 6

(4) Á

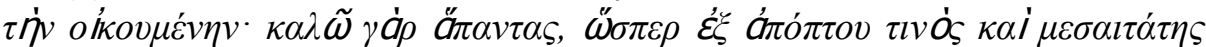

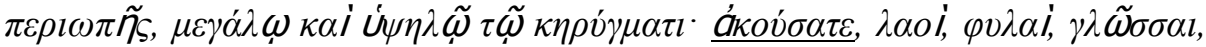

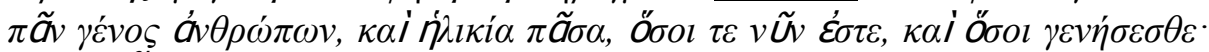

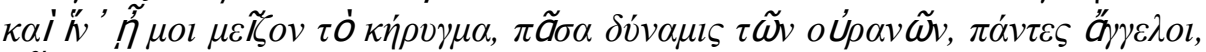

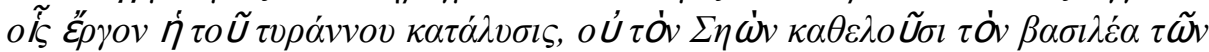

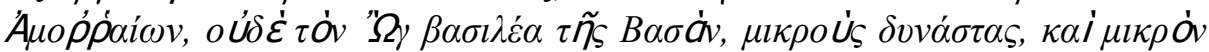

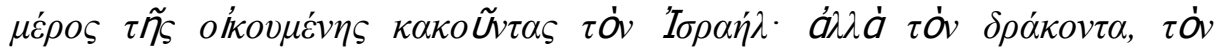

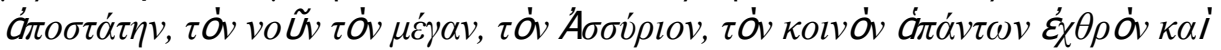

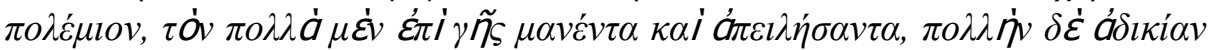

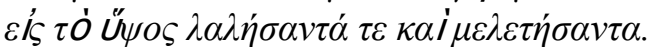

(Gregory Nazianzean's First Invective against Julian the Emperor 1)

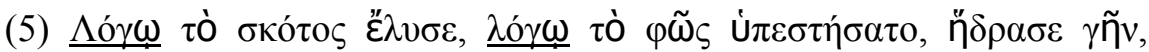

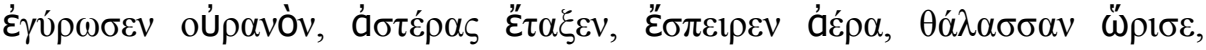

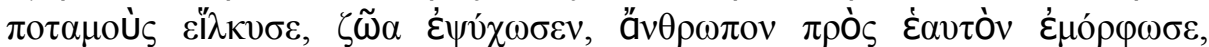

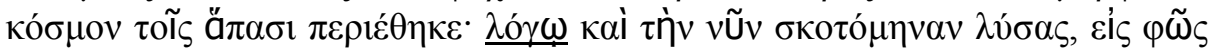

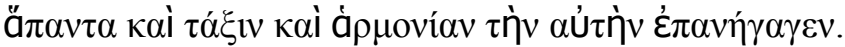

(Gregory Nazianzean's Second Invective against Julian the Emperor 31)

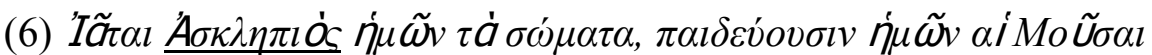

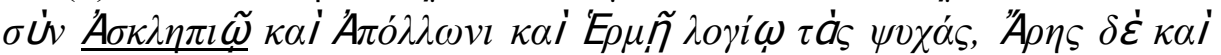

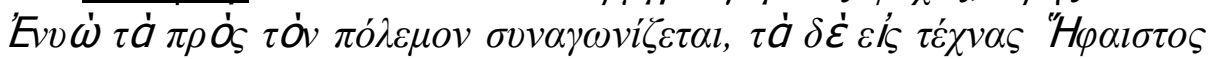

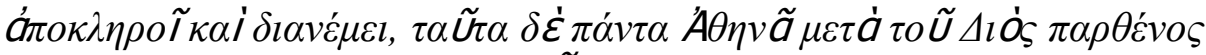

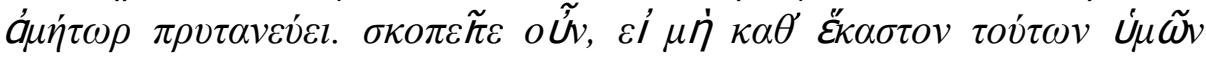

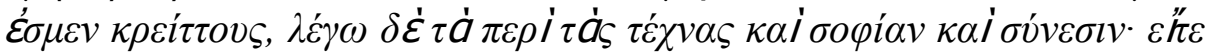

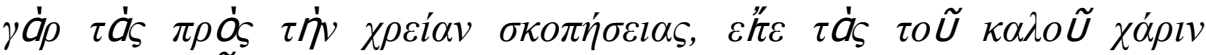

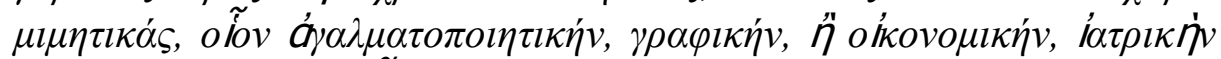

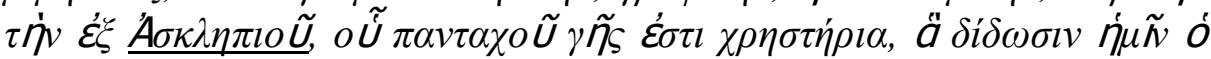

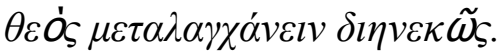

(Julian against Galileos 235a-c)

The repetition of the above underlined lexical elements has as a main goal to give emphasis and promote the orator's opinion about an issue. In example (4) through the repetition of the lexical element (ákov́ $\sigma \alpha \tau \varepsilon$ ) Gregory tries to motivate the audience's thought and ensures the conditional equality ${ }^{8}$ between text producer and public making them feel that they can participate in the text production. In examples (5) and (6) the repetition promotes and gives emphasis to the orator's thought.

\footnotetext{
${ }^{8}$ See Sornig (1989).
} 


\subsection{Appeal to authority}

Both speakers incorporate in their texts intertextualistic ${ }^{9}$ sources in order to strengthen their argumentation. Alexandropoulos (2012) supports that Julian in Against Galileos uses the intertextualistic sources with certain functions, such as evidence, contrast and background. In the next lines some examples of intertextuality enables us to understand the way of their functions in both orators.

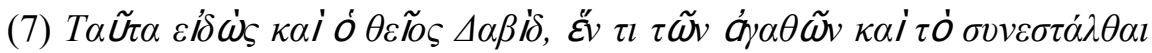

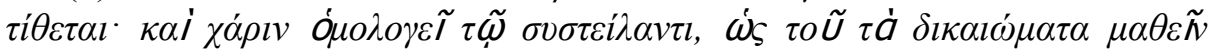

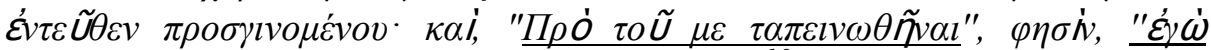

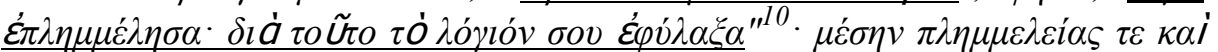

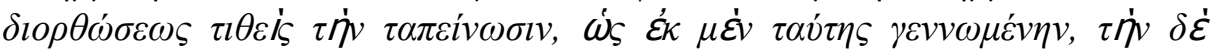

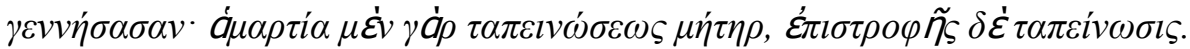
(Gregory Nazianzean's First Invective against Julian the Emperor 32)

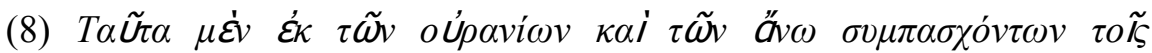

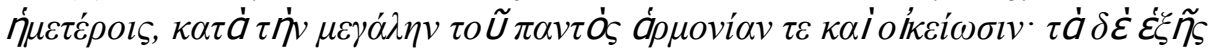

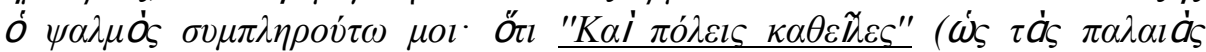

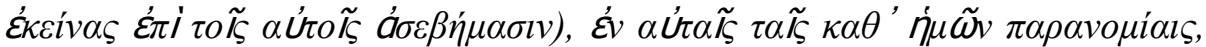

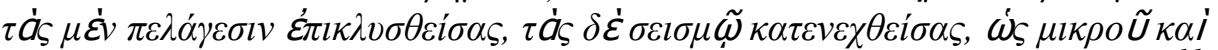

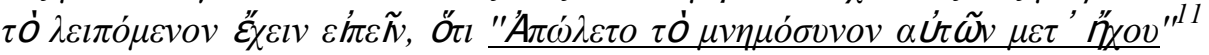

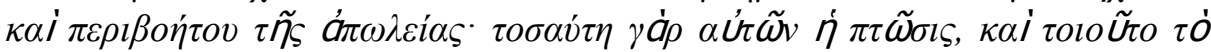

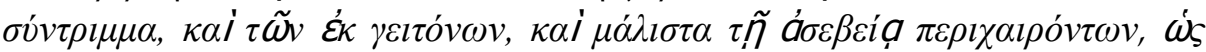

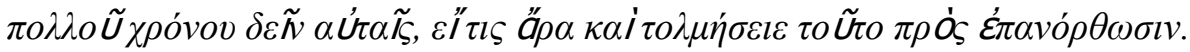
(Gregory Nazianzean's Second Invective against Julian the Emperor 6)

In examples (7) and (8) Gregory Nazianzean incorporates into his speech the intertextualistic source so as to prove and support his thought. In this way the orator promotes himself as an honest and reliable personality.

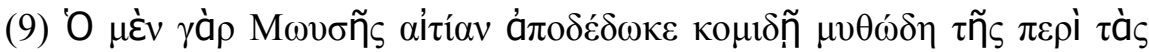

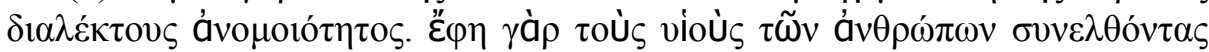

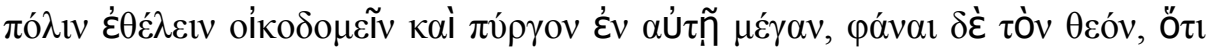

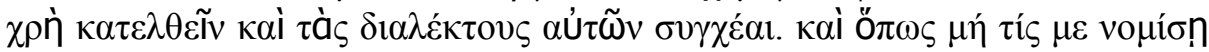

\footnotetext{
${ }^{9}$ For more information about intertextuality see de Beaugrande \& Dressler (1981), Bakhtin (1981·1986·1993), Kristeva (1980), Riffaterre (1978·1983·1990).

${ }^{10}$ Psalms $118,71$.

${ }^{11}$ Psalms 9,7.
} 


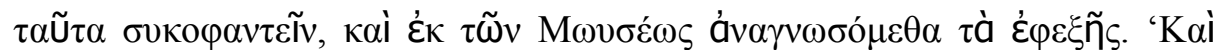

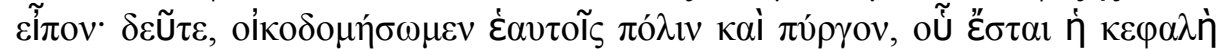

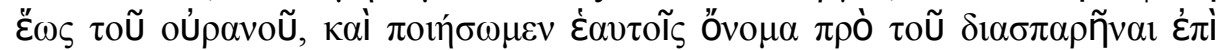

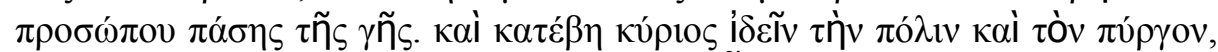

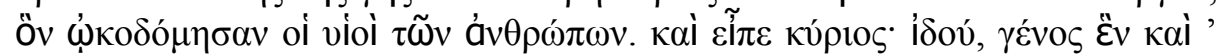

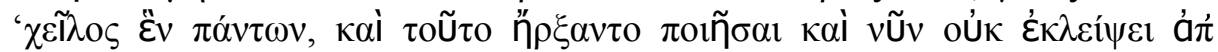

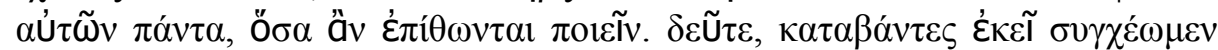

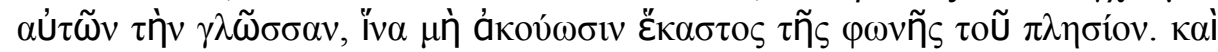

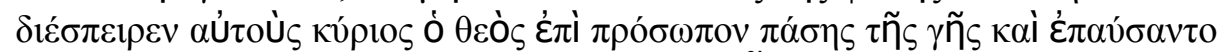

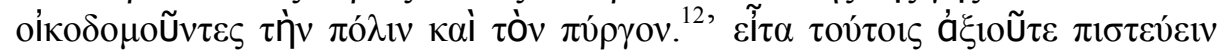

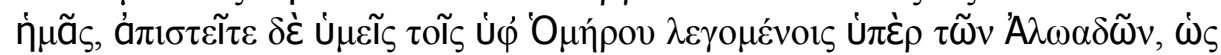

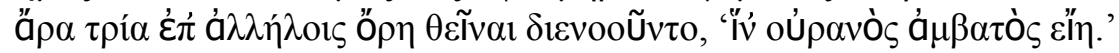
(Julian against Galileos 134d-135b)

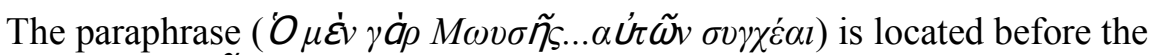

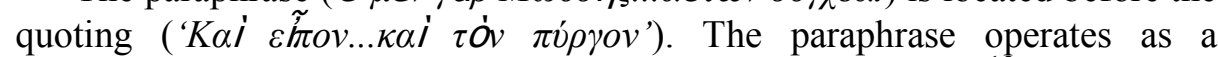
background of Julian's opinion that is next revealed with direct ${ }^{13}$ speech so as to support and enliven Julian's speech.

In general, it could be said that both orators use the intertextualistic sources as a means to legitimize their thoughts and promote themselves. Intertextuality gives the opportunity to the orator to get involved in the speech act and simultaneously to be detached from the context, as the intertextualistic source is more emphasized. Both orators have the ability to support themselves and have a favourable effect on the public about what they say by mixing voices and genres.

\subsection{Evaluative vocatives}

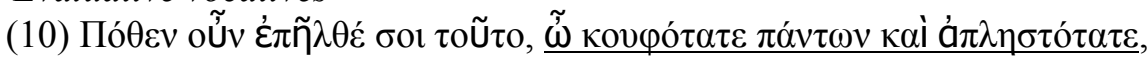

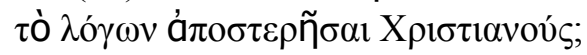

(Gregory Nazianzean's First Invective against Julian the Emperor 101)

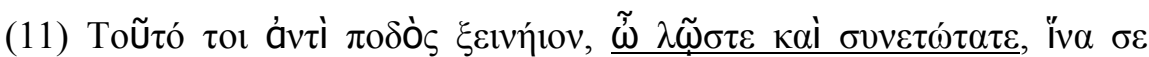

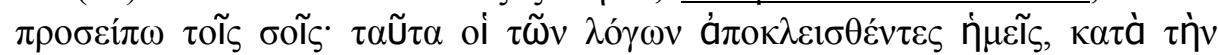

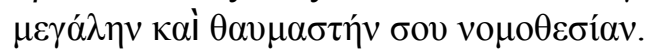

(Gregory Nazianzean's Second Invective against Julian the Emperor 39)

\footnotetext{
${ }^{12}$ Genesis $11.4-8$.

13 For more functions about the use of direct speech see Mayes (1990), Holt (19962000).
} 


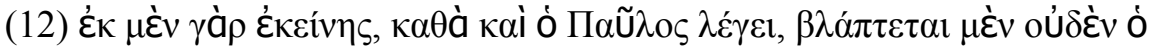

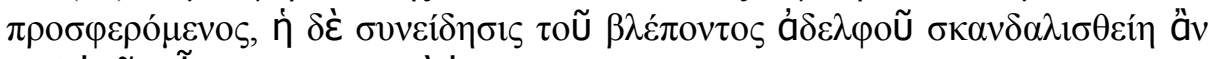

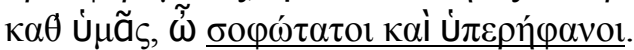

(Julian against Galileos 229cd)

In general the audience is forced to take part in the text production through vocatives. Besides this, in the above examples the superlative degree adjectives give an evaluative character to these vocatives, as they evaluate the political opponent with a dose of irony.

\subsection{Use of the personal Pronoun}

It is noted that both orators use the personal pronoun $\varepsilon^{\prime} \dot{\omega}$ before different verbs in order to state their opinion and express their intention. In Gregory's first speech the personal pronoun $\dot{\varepsilon} \dot{\omega}$ is followed by these verbs $\delta l \alpha \lambda \dot{\varepsilon} \xi o \mu \alpha l$ for commissive speech act and $o \tilde{\delta} \alpha$ for representative speech acts. In Gregory's second speech the personal pronoun is combined with these verbs: $\dot{\varepsilon} \xi \eta \gamma \dot{\eta} \sigma o \mu \alpha l, \quad \kappa \alpha \tau \alpha \lambda \dot{v} \sigma \omega, \quad$ o $\tilde{\delta} \alpha \alpha$ either in commissive speech acts or in representative as a means for the producer of the text to express his opinion. In his speech Against Galileos Julian combines with the below verbs:

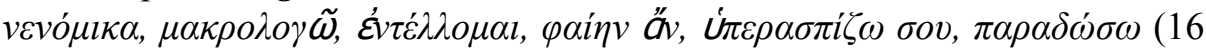
$\mathrm{N}$ of occurences), which are included either in representative or commissive speech acts. In addition, it is also worth mentioning that both orators use

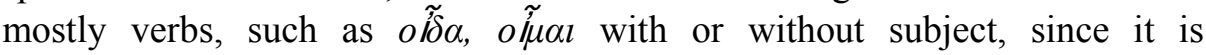
incorporated in the suffix in Greek. These verbs give them the opportunity to express his ideas, opinion and the knowledge they have about an issue because of their character.

Table 1. Frequency of private verbs $o_{\tilde{\mu} \mu \alpha \iota}^{\tilde{\mu}}$ and $\boldsymbol{\delta} \tilde{\delta} \alpha$

\begin{tabular}{|c|c|c|c|}
\hline $\begin{array}{l}\text { Private } \\
\text { Verbs }\end{array}$ & Gregory First Speech & $\begin{array}{l}\text { Gregory Second } \\
\text { Speech }\end{array}$ & $\begin{array}{c}\text { Julian Against } \\
\text { Galileos }\end{array}$ \\
\hline oĩuaı & $\mathrm{R}^{14} 284, \mathrm{~F}^{15} 6$ & $\mathrm{R} 448, \mathrm{~F} 2$ & R 127 F 11 \\
\hline oĩ் $\alpha$ & R 169, F 10 & R 259, F 6 & R 440 F 3 \\
\hline
\end{tabular}

Based on the above table we understand that Gregory prefers to use more than Julian the verb $o \tilde{\delta} \alpha$ (16 times in total). It must be said that this verb is mostly (14 times from 16) in negative form $\left(o U^{\prime} \kappa o \tilde{\delta} \alpha\right)$ and is accompanied by a clause. Through the negative forms the text producer expresses his opinion for the content of this clause and reveals his doubt about the truth of this

\footnotetext{
${ }^{14} \mathrm{R}$ means Rank.

${ }^{15}$ F means Frequency.
} 
clause. In two other cases, this verb is accompanied by adverbs such as $\varepsilon \tilde{U}$, as an indicator for displaying text's producer deep knowledge of what he says.

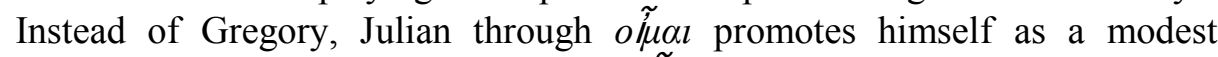
personality. In most cases the verb o $\tilde{\mu}$ al is used by both orators in a parenthetical way, as an attempt to express their opinion kindly and modestly.

Moreover, it is necessary to define the usage of the personal pronouns by both orators. For this reason the following table (3) lists the uses of the first and second personal pronouns by both orators.

Table 3. Personal pronouns usage

\begin{tabular}{|c|c|c|c|c|}
\hline Pronouns & $\begin{array}{l}\text { Gregory First } \\
\text { Speech }\end{array}$ & $\begin{array}{l}\text { Gregory } \\
\text { Second } \\
\text { Speech }\end{array}$ & $\begin{array}{l}\text { Total Amount } \\
\text { in Gregory's } \\
\text { Speeches }\end{array}$ & $\begin{array}{c}\text { Julian Against } \\
\text { Galileos }\end{array}$ \\
\hline $\begin{array}{l}\text { 1st person sg } \\
\text { reference } \\
\dot{\varepsilon} \gamma \dot{ }\end{array}$ & 6 & 6 & 12 & 6 \\
\hline 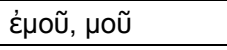 & 0 & 0 & 0 & 0 \\
\hline 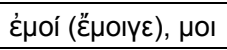 & 2 & 3 & 5 & 2 \\
\hline$\varepsilon \dot{\varepsilon} \mu \dot{\varepsilon}, \mu \varepsilon$ & 19 & 0 & 19 & 0 \\
\hline Total amount & 27 & 9 & 36 & 8 \\
\hline 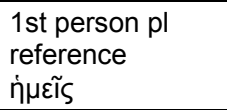 & 12 & 9 & 21 & 12 \\
\hline$\dot{\eta} \mu \tilde{\omega} v$ & 25 & 16 & 41 & 25 \\
\hline 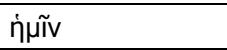 & 33 & 9 & 42 & 33 \\
\hline 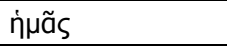 & 35 & 11 & 46 & 35 \\
\hline Total amount & 105 & 45 & 150 & 105 \\
\hline $\begin{array}{l}\text { 2nd person sg } \\
\text { reference } \\
\text { бù }\end{array}$ & 2 & 5 & 7 & 14 \\
\hline боบ̃, боU & 7 & 3 & 10 & 2 \\
\hline бoí, бo। & 15 & 7 & 22 & 15 \\
\hline$\sigma \varepsilon, \sigma \varepsilon$ & 4 & 0 & 4 & 0 \\
\hline Total amount & 28 & 15 & 43 & 31 \\
\hline 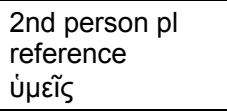 & 1 & 1 & 2 & 1 \\
\hline$\dot{u} \mu \tilde{\omega} v$ & 6 & 1 & 7 & 6 \\
\hline ù่uĨv & 12 & 1 & 13 & 12 \\
\hline ùuãs & 3 & 1 & 4 & 13 \\
\hline Total amount & 22 & 4 & 26 & 32 \\
\hline $\begin{array}{l}\text { Total of all 1st } \\
\text { and 2nd } \\
\text { personal } \\
\text { pronoun }\end{array}$ & 182 & 73 & 255 & 176 \\
\hline
\end{tabular}


Based on the above table it is seen that Gregory generally uses more frequently the 1st and 2nd personal pronouns than Julian does. It is worth mentioning that the first personal pronoun $(\dot{\varepsilon}) \dot{\omega})$ in singular is used with the same frequency (6 times) by both speakers in each of their speeches. The same thing happens with these types: $\sigma o i, \sigma o l, \dot{\eta}_{\mu \varepsilon} \tilde{\varepsilon}_{s}, \dot{\eta}_{\mu} \tilde{\omega} v, \dot{\eta}_{\mu} \tilde{N}, \dot{\eta}_{\mu} \tilde{a}_{\varsigma}, \dot{u} \mu \tilde{\omega} v$, $\dot{u} \mu \tilde{N}$ between Gregory's first speech and Julian's. In this way we could say that both orators, even though they differ in their political and theological orientation, they try through their speeches either to involve into the content of their text not only themselves but also the audience, or to be detached from the audience so as to express their ideas and thoughts. Last but not least, it is noted that Gregory in his second speech reduces the use of the personal pronouns in all cases except for the nominative of the first personal pronoun $\left(\varepsilon^{\prime}(\dot{\omega})\right.$ as a strategy of his communicative goal.

\subsection{Impersonal syntax}

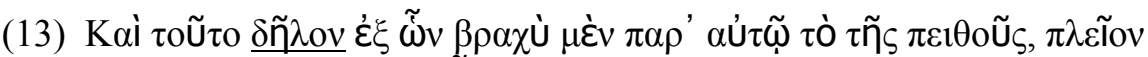

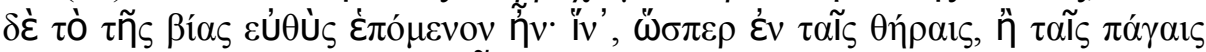

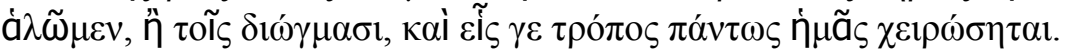
(Gregory Nazianzean's First Invective against Julian the Emperor 63)

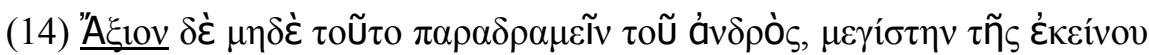

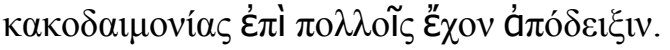

(Gregory Nazianzean's Second Invective against Julian the Emperor 14)

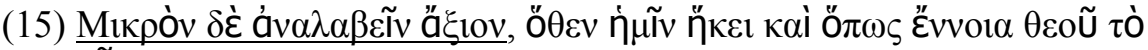

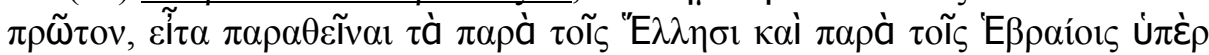

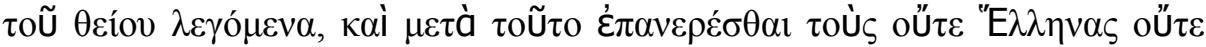

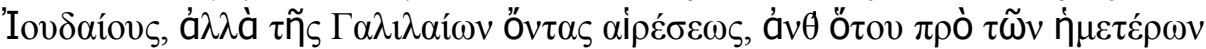

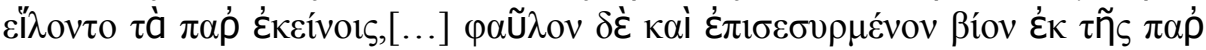

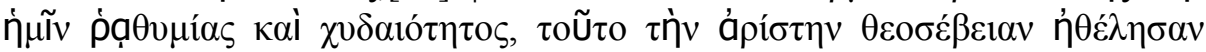
óvo $\mu \alpha \dot{\zeta} \varepsilon \sigma \theta \alpha$.

(Julian against Galileos 42e-43b)

In all the above examples both orators use impersonal syntax either with representative speech acts, so as to legitimize and give emphasis on their thought, or directive speech acts ( $\mu \iota \kappa \rho \dot{v} \delta \dot{\varepsilon} a \dot{v} \alpha \lambda \alpha \beta \beta \tilde{\varepsilon} \tilde{N} \not ̋ \xi o v)$ that give a more evaluative character to the message because of their deontic modality. 


\subsection{Contrast and antithesis ${ }^{16}$}

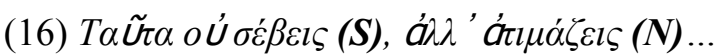

(Gregory Nazianzean's First Invective against Julian the Emperor 70)

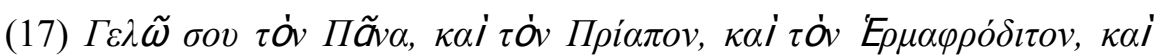

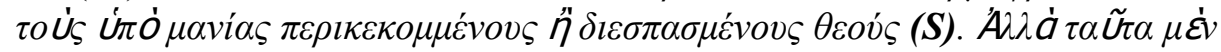

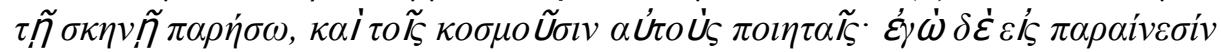

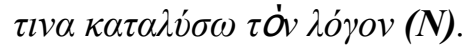

(Gregory Nazianzean's Second Invective against Julian the Emperor 32)

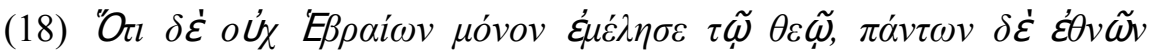

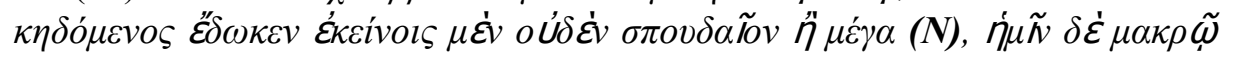
$\kappa \rho \varepsilon i \tau \tau o v \alpha \kappa \alpha i \delta \imath \alpha \varphi \varepsilon ́ \rho o v \tau \alpha, \sigma \kappa o \pi \varepsilon \tilde{\pi} \varepsilon \lambda o \imath \pi \dot{0} v \tau \dot{O} \varepsilon \dot{v} \tau \varepsilon \tilde{U} \theta \varepsilon v(N)$.

(Julian against Galileos 176ab)

In the above examples both orators try to persuade through the rhetorical relation of contrast and antithesis. In example (16) the antithesis is ensured through the syntactic schema oú... á $\lambda \lambda$ '; the main message of this structure is

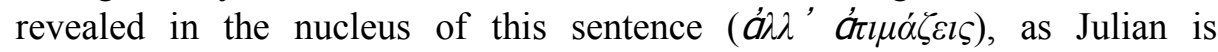
disapproved of his impiety. The disapproval operates as a means for Gregory's praise. In the same way example (17) contributes to the text's producer's goal as he states that he will give an encouraging character to his speech and will stop any kind of disapproval and ridicule.

In example (18) the metalinguistic expression $\sigma \kappa o \pi \varepsilon \tilde{\pi} \varepsilon \lambda o \imath \pi \dot{\alpha} \tau \dot{\partial} \varepsilon \dot{v} \tau \varepsilon \tilde{U} \theta \varepsilon v$ gives the opportunity to Julian to invoke the audience attention as a directive speech act. Besides this, the antithetical conjunction ( $o \mathcal{U}_{\chi} \mu o ́ v o v-\delta \varepsilon$ ) and the

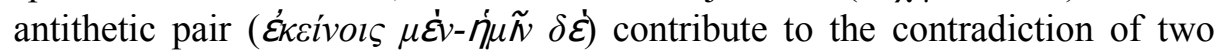
theological systems. The orator leads the public to make this certain comparison through the relation of contrast, as he wants to give emphasis on the negative characteristics of the empire with reference the theological system that must change. If these characteristics change, then his political goal for improvement and elaboration will be achieved. To sum up, in all the examples the rhetorical relations of antithesis and contrast promote the text producer and enable him to have a favourable effect on the public.

\subsection{Lexical similarities}

For the purposes of this analysis at this point follows table 2 with the most frequently used words in order to draw some conclusions about the vocabulary used by orators examined.

\footnotetext{
${ }^{16}$ For more information about coherence see de Beaugrande \& Dressler (1981), Mann \& Thompson (1986 1988), Hoey (1993) and Winter (1977).
} 
Table 2. The most frequent content words in both orators

\begin{tabular}{|c|c|c|c|}
\hline \multicolumn{2}{|r|}{$\begin{array}{l}\text { Gregory Nazianzean } \\
\text { Word Frequency }\end{array}$} & \multicolumn{2}{|r|}{$\begin{array}{c}\text { Julian } \\
\text { Word Frequency }\end{array}$} \\
\hline ^óyos & 85 & Өદós & 213 \\
\hline Oعós & 65 & Mwuoñs & 50 \\
\hline 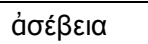 & 38 & 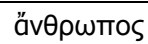 & 48 \\
\hline Xpıбtıavós & 38 & ^óyos & 34 \\
\hline 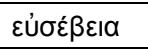 & 23 & Kúpıos & 18 \\
\hline Xрıбтós & 16 & $\Psi_{\text {uxń }}$ & 15 \\
\hline чuxń & 15 & 'Iouঠaíoı & 12 \\
\hline 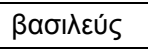 & 14 & oĩuaı & 11 \\
\hline 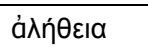 & 13 & $\mu \tilde{a} \lambda \lambda \mathrm{ov}$ & 12 \\
\hline 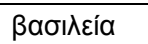 & 13 & Xpıбтós & 8 \\
\hline
\end{tabular}

Even though they are two personalities with different political and theological thoughts and beliefs they use a basic, core vocabulary that gives them the opportunity to express their ideas about their theological system. It seems that these words have a moral content and reflect the importance of certain concepts for the policies of these two orators. These words also reflect the theological system of that period which was based on piety before the Gods.

\subsection{Appeal to logic}

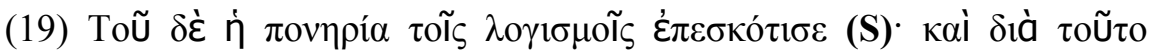

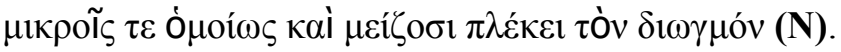

(Gregory Nazianzean's First Invective against Julian the Emperor 75)

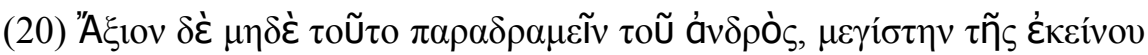

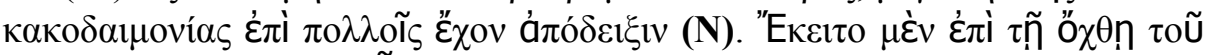

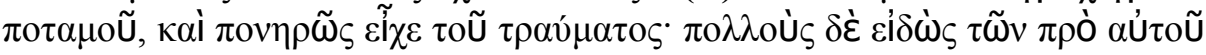

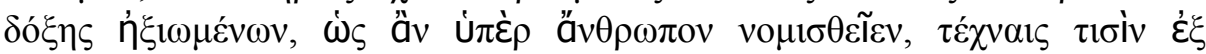

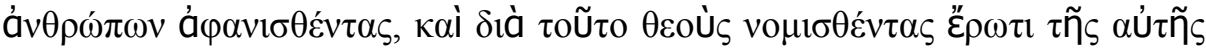

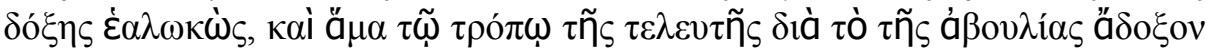

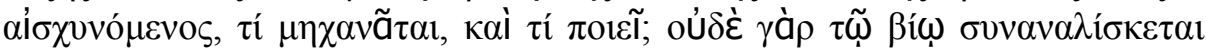

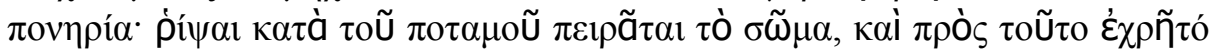

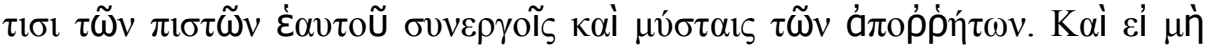

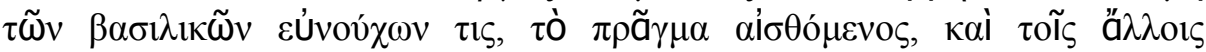

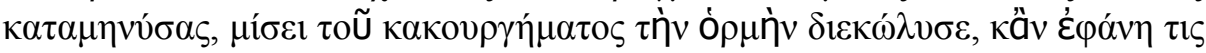

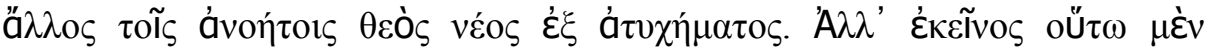

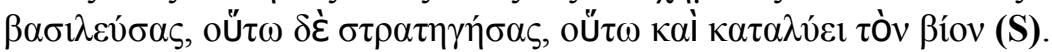

(Gregory Nazianzean's Second Invective against Julian the Emperor 14) 
VOLUME 6

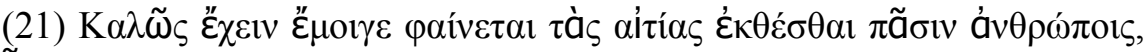

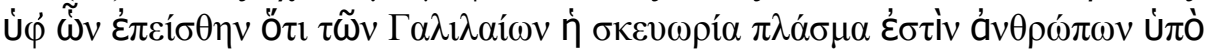

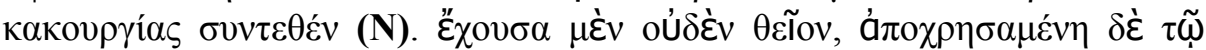

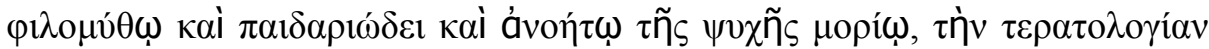

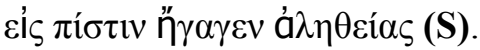

(Julian against Galileos 39ab)

Both orators resort to argumentative rhetorical relations as part of a logical organization pattern. In example (19) through the rhetorical relation of cause Gregory tries to explain the Julian's behavior against Christians. In example (20) through the rhetorical relation of evidence he tries to prove Julian's misfortune. Through the relation of evidence in example (21) Julian tries to prove that Christianism uses myths as a means in order to deceive people. To crown it all, both orators try through the argumentative relations (cause, evidence) and their text organization to persuade and explain to the public everything they talk about.

\section{CONCLUSION}

Through the above multidisciplinary analysis it is fully understood that Julian and Gregory Nazianzean use some rhetorical strategies that promote their rhetorical and communicative goals. Most of the certain ideological strategies are used in the same way aiming at catching the attention and maintaining the interest of their audience. This does not mean that both orators do not have their personal style, but it means that their ideological and political goal leads them to prefer certain strategies so as to have a favourable effect on public. In this way, no one can deny that orators relv on political holistic characteristics and systematic rhetorical mechanisms in order to persuade.

\section{REFERENCES}

Alexandropoulos, G. (2012). Text and context in Flavius Claudius Julian's political speeches: coherence, intertextuality and communicative goal. $\mathrm{PhD}$ Thesis. University of Athens.

Athanassiadi, P. (1992). Julian: an intellectual biography. London: Routledge.

Bakhtin, M. (1981). Discourse in the Novel. In: Holquist, M. (ed.), The Dialogic Imagination. Austin: University of Texas Press.

Bakhtin, M. (1986). Speech Genres and Other Late Essays. (Trans. by Vern W. McGee). Austin: University of Texas Press.

Bakhtin, M. (1993). Toward a Philosophy of the Act. (Ed. V. Liapunov and M. Holquist. Trans. Vadim Liapunov). Austin: University of Texas Press.

Bernardi, J., Mossay, J., Gallay, P. (1978). Discours, Grgoire de Nazianze; introduction, texte critique, traduction et notes. Sources Chretiennes. Paris: Editions du Cerf. 
de Beaugrande, R. \& W. Dressler (1981). Introduction to Textlinguistics. London: Longman.

Biber, D., \& R. Reppen (2011). Corpus Linguistics; Volume One: Lexical Studies. London: Sage.

Borg, J. $\left(2007^{2}\right)$. Persuasion - The Art of Influencing People. London: Pearson / Prentice Hall.

Chafe, W. (1982). Integration and involvement in speaking, writing and oral literature. In: Tannen, D. (ed.), Spoken and written language. Notwood: Ablex, $35-55$.

van Dijk, T. A. (1999). Towards a Theory of Context and Experience Models in Discourse Processing. In: van Oostendorp, H. \& S. Goldman (eds.), The Construction of Mental Representations during Reading. Hillsdale, NJ: Erlbaum, 123-48.

van Dijk, T. A. (2001). Discourse, Ideology and Context. Folia Linguistica XXX (12): $11-40$.

Fairclough, N. (1992). Discourse and social change. Cambridge: Polity Press.

Fairclough, N. (2000). Discourse, social theory, and social research: the discourse of welfare reform. Journal of Sociolinguistics 4 (2): 163-195.

Fairclough, N. \& Wodak, R. (1997). Critical discourse Analysis. In: van Dijk T. A. (ed.), Discourse as Social Interaction. London: Sage Publications, 258-284.

Hoey, M. (1993). A common signal in discourse: how the word "reason" is used in Texts. In: Sinclair, J. M., G. Fox \& M. Hoey (eds.), Techniques of Description in Spoken and Written Discourse: A Tribute to Malcolm Coulthard. Taylor \& Francis, London.

Holt, E. (1996). Reporting on Talk: The Use of Direct Reported Speech in Conversation. In Research on Language and Social Interaction 29 (3): 219-245.

Holt, E. (2000). Reporting on Reacting: Concurrent Responses to Reported Speech. In Research on Language and Social Interaction 33(4): 425-454.

Johnstone, B. (1989). Linguistic strategies and cultural styles for persuasive discourse. In: Ting-Toomey, S. \& F. Korzenny (eds.), Language, communication and culture: current directions. Newbury Park: Sage, 139-156.

Kristeva, J. (1980). Desire in Language. Oxford: Basil Blackwell.

Mann, W. C. \& S. A. Thompson (1986). Relational propositions in discourse. Discourse Processes 9 (1): 57 - 90.

Mann, W. C. \& S. A. Thompson (1988). Rhetorical Structure Theory: towards a functional theory of text organization. Text 8 (3): $243-281$.

Mayes, P. (1990). Quotation in spoken English. In Studies in Language 14(2): $325-$ 363.

McGuckin, J. (2001). Saint Gregory of Nazianzus: An Intellectual Biography. Crestwood, NY.

Migne, J. P. (1857-1866). Patrologiae Graecae Cursus Completu.

Riffaterre, M. (1978). Semiotics of Poetry. Bloomington \& London: Indiana University Press.

Riffaterre, M. (1983). Text Production. New York: Columbia University Press.

Riffaterre, M. (1990). Compulsory Reader Response: The Intertextual Drive. In: Worton, M. \& Still, J. (eds.), Intertextuality: Theories and Practices. Manchester: Manchester University Press, 56-78. 


\section{VOLUME 6}

Roberts, W.R. (1984). The Rhetoric and the poetics of Aristotle. New York: The Modern Library.

Searle, J. (1969). Speech Acts: An Essay in the Philosophy of language. Cambridge: Cambridge University Press.

Searle, J. R. (1979). Expression and Meaning. Studies in the Theory of Speech Acts. Cambridge: Cambridge University Press.

Searle, J. R. (1994). How Performatives Work. In: Harnish, R. M. (ed.), Basic Topics in the Philosophy of Language. London: Harvester Wheatsheaf, 75-95.

Searle, J. R. (1996a). What is a Speech Act? In: Martinich, A. P. (ed.), The Philosophy of Language. Oxford: Oxford University Press, 130-140.

Searle, J. R. (1996b). Indirect Speech Acts. In: Martinich, A. P. (ed.), The Philosophy of Language. Oxford: Oxford University Press, 168-182.

Sornig, K. (1989). Some remarks on linguistic strategies of persuasion. $\Sigma \tau$ o: Wodak, R. (ed.), Language, Power and Ideology. Studies in political discourse. Amsterdam / Philadelphia: John Benjamins Publishing Company, 95-113.

Wright, W. C. (1912-1913). The works of the emperor Julian. London: Loeb Clas. Libr.

Winter, E. (1977). A clause relational approach to English texts: a Study of some predictive items in written discourse. Instructional Science 6/1: 1-92. 